REGULAR ARTICLE

\title{
SELECTION OF NEW PROMISING SEEDLESS MANDARINS TRIPLOID HYBRIDS FROM CROSSES BETWEEN MONOEMBRYONIC DIPLOID FEMALE AND DIPLOID MALE PARENTS
}

\author{
HANDAJI NAJAT ${ }^{*}$, HAMID BENYAHIA, NAJAT ARSALANE, HASSAN BENAOUDA
}

Institut National de Recherche Agronomique, BP.257, Kenitra, Morocco

\begin{abstract}
Morocco is one of the major exporters of small citrus fruits, such as mandarin and Clementine. Seedlessness is a major criterion for this horticultural group. The present study focused on the selection of the best triploid mandarin hybrids $(2 n=3 x=27)$ characterized by seedless fruits. A series of crosses between 'Sidi Aissa' clementine (female parent) and seven mandarin varieties ('Lee', 'Wilking', 'Osceola', 'Carvalhal', 'Satsuma Frost', 'Satsuma Owari' and 'Chienka') was performed by the National Institute for Agricultural Research. Forty triploid mandarins were obtained and planted since 2002 in an experimental field at El Menzeh. Varietal evaluation was focusing on fruit quality traits during seven years. Statistical analyzes showed that there is a significant difference for all studied characters and between hybrids. The number of seeds per fruit is the main criterion which differentiates between triploids mandarin's hybrids and their diploid parent "clementine Sidi Aissa". The best hybrids selected were: HT11, HT13, HT27, HT43, HT44, and HT49. The best crosses are C1 ('Sidi Aissa' × 'Wilking') andC2 ('Sidi Aissa' $\times$ 'Osceola'). These promising triploid hybrids of mandarin have been multiplied on several rootstock trials and are in the process of quantitative evaluation and multi-site testing.
\end{abstract}

Keywords: Morocco; Citrus spp.; mandarins; breeding program; triploidy; fruit quality

\section{INTRODUCTION}

The citrus sector is the largest fruit's production in both value and volume in the world economy. In recent years, the consumption of small citrus fruits, particularly clementines and mandarins, has grown rapidly in the international market. Fruit quality is the determining factor in the commercial value of Citrus crop. A number of variable criteria define the quality requirements of citrus fruits. Citrus quality standards depend on their variety, just as their region of production and market is expressed $[1,2]$.

Seedlessness major economic characteristic of mandarins which determines the market value, and mandarin triploid hybrids bears this important trait [3]. Triploid citrus cultivars $(2 n=3 x=27)$ have great commercial potential [4]. Triploid embryos will rarely germinate and found in smaller seeds [5]. Otherwise, these triploid plants can be obtained from the crosses of two diploid genotypes by fertilization of $2 \mathrm{n}$ mega gametophyte [6-13]. Spontaneous triploids also occur in about $5 \%$ of the seeds obtained from diploid parents. They are found in the small seed, weighing less than $0.1 \mathrm{~g}$. In addition, triploid hybrids can be produced by crossing a diploid parent and a tetraploid parent. If mono-embryonic zygotic diploid genotypes are used as the female parent and tetraploid genotypes as the male parent, many poorly developed seeds are produced [14-16,3]. These triploids can be derived either from the union of unresolved female gametes with reduced male gametes $(18+9)$, or from the fusion of reduced female gametes with unreduced male gametes $(9+18)$ [17-19]. Hybridization and embryos rescue are a promising method for production of triploid hybrids yielding seedless fruit. The present study focused on the evaluation of 40 triploid new mandarin's hybrids from crosses between diploid parents.

\section{MATERIALS AND METHODS}

\section{Plant material}

Forty new triploid hybrids of mandarin trees were obtained after a series of directed crosses and shared common female parent (half sibling). Thus, seven combinations have been highlighted and each one of them was constituted by full siblings. The Clementine 'Sidi Aissa' was used as a female parent since it is mono-embryonic, self-incompatibility and very appreciated by high production and good quality. Seven mandarin's cultivars were therefore, used as male parents (table 1). These hybrids were regenerated from abortive seeds. These were sterilized and cultured on Murashige and Skoog (MS) basal medium supplemented with $500 \mathrm{mg} \mathrm{L}^{-1}$ malt extract (ME)

Received 01 November 2017; Accepted 29 December 2017

*Corresponding Author

Handaji Najat

Institut National de Recherche Agronomique, BP.257, Kenitra, Morocco

Email: nhandaji2002@yahoo.fr

( This article is open access and licensed under the terms of the Creative Commons Attribution License (http://creativecommons.org/licenses/by/4.o/) which permits unrestricted, use, distribution and reproduction in any medium, or format for any purpose, even commercially provided the work is properly cited. Attribution - You must give appropriate credit, provide a link to the license, and indicate if changes were made. 
and $1 \mathrm{mg} \mathrm{L} \mathrm{L}^{-1}$ gibberellic acid $\left(\mathrm{GA}_{3}\right)$, and kept at $26 \pm 1{ }^{\circ} \mathrm{C}$ with 16 -h photoperiod. Seedlings at the five-leaf stage were transferred into plastic pots containing garden soil and kept in a greenhouse. Triploid seedlings were identified by flow cytometry (Sysmexpartec/Cyflow Space) (fig. 1). They were grafted on 'Troyer' citrange rootstock and planted at a spacing of $6 \times 4 \mathrm{~m}$ in April 2002 .

\section{Characteristics of the experimental site}

The experiment was carried out at El Menzeh experimental area (INRA Kenitra, Morocco). The climate is of the Mediterranean type belonging to the sub humid area. The soil is of the sandy type at the surface (98\%) and sandy-clayey at depth, with a pH of 6 , a retention capacity of 3 to $6 \%$, a cation exchange capacity of $5 \mathrm{meq} 1 \mathrm{Oog}^{-1}$ with no limestone. The quantities of water needed to properly irrigate the plot are defined according to the climatic zone. The citrus water requirements are estimated at around $1,200 \mathrm{~mm}$ per year, spread over the whole year. The experimental period is characterized by an average annual rainfall of $511 \mathrm{~mm}$. The 589 to $689 \mathrm{~mm}$ deficit was filled by irrigation from May to September-October (micro-jet) with modulated intakes based on potential evapo-transpiration values. Over seven years of observations, the average annual temperature was $16^{\circ} \mathrm{C}$ with an average maximum of $22{ }^{\circ} \mathrm{C}$ and an average of the minimum of $10{ }^{\circ} \mathrm{C}$. For the conduct of the test, nitrogen fertilization (amonitrate 33.5\%) was carried out on the basis of three annual intakes distributed according to the following proportions: $50 \%$ before flowering, $25 \%$ after flowering and $25 \%$ after physiological fall. Contributions of potassium sulfate and triple superphosphate were respectively made in September and December.

\section{Characters to be evaluated}

The fruit ripeness of the new triploid hybrids started from the first week of October. Thus, samples of 30 fruits per replicate were randomly collected at harvest date for determining physical and chemical characteristics. Juice analysis was performed at precise dates during seven years: D1(22/10/2007); D2(16/10/2008); D3(07/10/2009); D4(29/10/2010); D5(26/10/2011); D6(29/10/2012) and D7(17/10/2013). To obtain representative samples, a fruit collection was done on two trees per hybrid.

\section{Juice content}

The juice extraction for analysis was performed in the laboratory of INRA El Menzeh according to the standards [20]. The production of a blended juice per accession was carried out by a rotary extractor. The collected juice was filtered through a plastic filter and weighed. The juice content was expressed as a percentage offresh weight following the formula: Juice content

$$
\text { (\%) }=\frac{\text { Weight of juice extracted from } 30 \text { fruits }}{\text { Total weight of } 30 \text { fruits }} \times 100
$$

\section{Total soluble solids}

The sugar content was estimated by the total soluble solids (TSS) determined by digital benchtop refractometer (BellinghamandStanley RFM700-M). A drop of each sample fruit juice was deposited on the prism and the reading of the soluble solids (in ${ }^{\circ} \mathrm{Brix}$ ) was made at room temperature.

Table 1: List of new mandarin hybrids from crosses between clementine 'Sidi Aissa' and eight male parents of mandarin (HT: triploid hybrid)

\begin{tabular}{llll}
\hline Crosses & Mandarins ( $\left.{ }^{\wedge}\right)$ & Clementine 'Sidi Aissa' (+) & $\begin{array}{l}\text { Hybrids } \\
\text { number }\end{array}$ \\
\hline C1 & Wilking & HT10 HT11 HT12 HT13 HT14 HT15 HT16 HT17 HT19 HT20 HT21 HT22 & 21 \\
& & HT23 HT24 HT25 HT27 HT28 HT29 HT48 HT50 HT53 & 7 \\
C2 & Osceola & HT5 HT43 HT44 HT46 HT51 HT52 HT56 & 6 \\
C3 & Chienka & HT30 HT32 HT33 HT34 HT36 HT61 & 2 \\
C4 & Satsuma Frost & HT7 HT8 & 1 \\
C5 & Carvalhal & HT49 & 1 \\
C6 & Lee & HT6 & 2 \\
C7 & Satsuma Owari & HT47 HT59 & \\
Total & 7 & 40 &
\end{tabular}
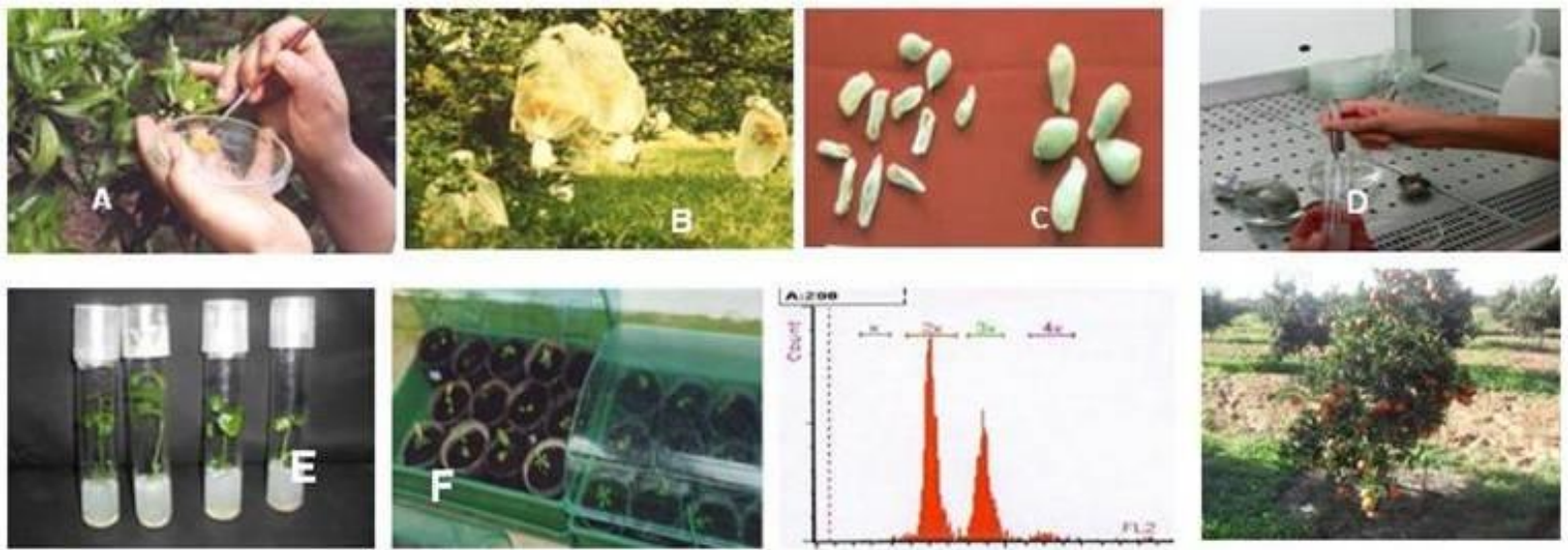

Fig. 1: Production phases of mandarin triploids hybrids. A: Pollination; B: Fruits from crosses; C: Abnormal seeds on the left; $D$ and E: In vitro germination of immature embryos; F: Acclimatization phase in greenhouse; G: Histogram of flow cytometry for DNA amount counting; and H: Grafting and production of triploid hybrids 


\section{Juice acidity}

Juice acidity was measured by titration. $10 \mathrm{ml}$ of the decanted juice were used and three drops of phenolphthalein (1g10o ml-1 ethanol) were added. The titratable acidity (TA) is obtained according to the following formula: $\mathrm{TA}=\frac{\mathrm{Vs}}{10}$. Where $V s$ is the volume of $\mathrm{NaOH}(\mathrm{ml})$ used for the titration and $10(\mathrm{~mL})$ is the volume of juice used.

\section{Maturity index}

The citrus fruit behaves like a non-climacteric organ. If harvested before maturity, it will never acquire suitable organoleptic qualities [21] The maturity index (MI) is a criterion widely used in the determination of the maturity or ripening date (for harvesting) citrus fruit. It is determined by the ratio: $\mathrm{MI}=\frac{\mathrm{TSS}}{\mathrm{TA}}$, where TSS is the sugar content estimate ( ${ }^{\circ} \mathrm{Brix}$ ) and $T A$ is the Titratable acidity of the juice.

\section{Average weight of a fruit}

This average is determined by measuring total weight of 30 fruits per accession. It was appreciated using an electric scale (Platform scale/EBW-6o).

\section{Fruits morphological description}

The selected hybrids were characterized by the following pomological criteria recorded on 10 fruits per accession: fruit diameter and length $(\mathrm{mm})$, diameter/length ratio, fruit shape (ellipsoid, pyriform, obloid, round), fruit skin (orange, orange yellow, yellow), thickness of segment wall (thin $(<2 \mathrm{~mm})$, medium $(2 \mathrm{~mm}<<6 \mathrm{~mm})$ or thick $(>6 \mathrm{~mm})$, and adherence of segment walls (weak, medium, strong).

\section{Statistical analysis}

Quantitative data were analyzed using SAS (Statistical Analysis System version 9.1 and version 5.5) and were subjected to analysis of variance (ANOVA), and means were compared with Duncan test at $5 \%$ level of significance.

\section{RESULTS AND DISCUSSION}

\section{Quality of the triploid fruits}

A highly significant difference was observed between the genotypes for all the studied criteria while the year effect was not significant for the variables number of seeds per fruit and the maturity index (E/A) (tables 2, 3, 4). Likewise, the [year $\times$ genotype] interaction was not statistically significant. The data expressed a rather large variability in the profile of each hybrid compared to that of their female parent the Clementine 'Sidi Aissa'. There was a highly significant difference between the mandarin hybrids for all the criteria studied. The number of seeds ranged from $o$ to 3 according to the new mandarin's hybrids, with $75 \%$ of the hybrids having o or 1 seed per fruit (fig. 2), compared to 7 seeds per fruit for the control Clementine 'Sidi Aissa'. Generally, the triploid causes male and female sterility, preventing cross-pollination on incompatible cultivars [5,11]. Seedlessness is an important criterion for distinguishing and selecting new mandarin varieties [23]. The average fruit weight of mandarin hybrids was $77 \mathrm{~g}$, in a range of $48 \mathrm{~g}$ to $125 \mathrm{~g}$. The triploid hybrids HT19 and HT24 yielded the maximum fruit weight (98g and 108g, respectively) whereas the hybrids HT10 and HT21 had small sized fruits (47g and 50g, respectively). Furthermore, $18 \%$ of the hybrids had a higher average fruit weight than that of the control 'Sidi Aissa' (88g). This criterion is important in marketing but influenced by climatic factors, the date of harvest and the position of fruit in the tree $[24,26]$. In addition, the juice content varied from $24 \%$ to $56 \%$ with an average of $44 \%$. The triploid hybrids HT17, HT10 are the juiciest whereas HT32 and HT12 hybrids have the least juicy fruit. In addition, $28 \%$ of the hybrids studied have a percentage of juice higher than that of the control 'Sidi Aissa' (44\%). This parameter increases at maturity and is used as a standard marketing index. It depends on the species and the destination market. Indeed, are the most requested and the most appreciated by consumers. As the others traits, the juice content can be improvement because it varies according to the varieties, the stage of maturity, the exposure and the positioning of the fruits in the tree, the contribution of fertilizers and the climatic conditions [2734]. Also, variance analyze showed that acidity is highly variable across the 40 hybrids and as a result, several statistical groups were highlighted. The acidity ranged from 0.36 (HT5) to 1.87 (HT10) while the control has an acidity of 0.87 . Similarly, $88 \%$ of hybrids have higher acidity than the control.

In addition, the sugar content ranged from 8.20 to 11.55 with an average of 9.89. Triploid HT17 and HT16 hybrids have been characterized by the highest value while $\mathrm{HT}_{5}$ and HT8 hybrids are the least sweet. 15\% of triploid hybrids have sweeter fruits than those of the control. Otherwise, the maturity index (E/A), an indicator of fruit ripeness, ranged from 6 to 23. The hybrids HT5, HT17 are the earliest, while the hybrids HT8, HT10, HT11 and HT5O are relatively late. So, $13 \%$ of the hybrids ripen three weeks later than its parental "Sidi Aissa". Usually, this variable is low in early-picking fruits compared to late-picking fruits. Generally, all fruit quality criteria are variables with the exception of seedlessness which is a central issue in the development of Citrus sector. Although, researchers continue to search for the right combination of factors that improve citrus fresh fruits quality, because it's influenced by many factors, including, rootstock, production techniques, environmental conditions [25, 26, 31, 35-39]. The seedless mandarin hybrids selected will be grafted on some rootstocks and tested in several areas.

\section{Effect of the male parent on the variability of the fruit quality}

The triploid hybrids of mandarin tree obtained from the cross (C4) [clementine 'Sidi Aissa' $\times$ mandarin 'Satsuma Frost'] were characterized by their capacity to develop seeds ( 2 to 4 seeds per fruit). While, the hybrids from the others crosses produce seedless fruits (o or 1 seed per fruit) (table 5). The average weight fruit was relatively low in hybrids from the combination [Sidi Aissa $\times$ Satsuma Owari]. However, the combination [Sidi Aissa $\times$ Carvalhal] was identified by the highest values for both the sugar content and the average fruit weight. The combination [Sidi Aissa $x$ Chienka] was characterized by a high value of the juice percentage. While, the combination [Sidi Aissa $\times$ Wilking] was distinguished by a high value of acidity. Previous studies reported that in triploid progeny, the codified characteristic of many genes (fruit size and flavor) seemed to be strongly influenced by the tetraploid parent [15]. The same authors obtained triploid hybrids resembled the male parent tetraploid in fruit size, easy of peeling, and varying degrees 
of anthocyanin pigmentation that increased as with the maturity of the fruits. Likewise, [40] showed that the male parent has a large influence on the offspring and male parents with a deeper orange bark color, larger fruit size, better fruit shape and higher internal quality have resulted to families with an improvement of the population. Therefore, only male parents of the highest quality should be used in breeding programs to increase the chances of obtaining a new high quality cultivar. While, the female parent would be preferable self incompatible and monoembryony as the case of clementine. The best combinations are Sidi Aissa X Wilking (HT11, HT13, T25, HT27); Sidi Aissa X Osceola (HT43, HT44, HT51, HT52); Sidi Aissa X Chienka (HT33) and Sidi Aissa X Caravalhal (HT49). Also, Ray [1] showed that high variability among F1 hybrids is due to the high heterozygosity that occurs in Citrus.

Table 2: Synthesis of statistical results of the quality criteria of all triploid hybrids of mandarin trees (El Menzeh, INRA, 2007-2013)

\begin{tabular}{|c|c|c|c|c|c|c|c|}
\hline Crosses & Hybrids & $\begin{array}{l}\text { Fruit weight } \\
\text { (g) }\end{array}$ & $\begin{array}{l}\text { Fruit } \\
\text { seed } \\
\text { number }\end{array}$ & $\begin{array}{l}\text { Juice } \\
\text { content } \\
(\%) \\
\end{array}$ & $\begin{array}{l}\text { Acidity } \\
\text { (TA) }\end{array}$ & $\begin{array}{l}\text { Soluble solids } \\
\text { ( }{ }^{\circ} \text { Brix) (TSS) }\end{array}$ & $\begin{array}{l}\text { Maturity } \\
\text { index } \\
\text { (TSS/TA) }\end{array}$ \\
\hline \multirow{28}{*}{ 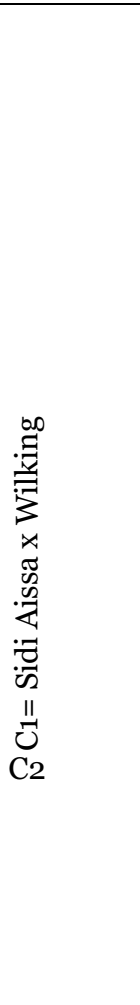 } & HT10 & 47.91 & $0.4 \mathrm{~cd}$ & $49 \cdot 3 \mathrm{ab}$ & $1.8 \mathrm{a}$ & 10.9abcd & 6.of \\
\hline & HT11 & $89.2 \mathrm{bcdef}$ & $0.4 \mathrm{~cd}$ & $43.3 \mathrm{bcdef}$ & $1.7 \mathrm{ab}$ & 10.5abcdefg & $6.4 \mathrm{ef}$ \\
\hline & HT12 & 78.8cdefghij & $3.6 \mathrm{~b}$ & $23.6 \mathrm{i}$ & o.9cdefgh & 8.9ijk & 10.2bcdef \\
\hline & HT13 & 80.7cdefghi & $0.9 \mathrm{~cd}$ & 38.4bcdefgh & 1.3abcdef & 10.3abcdefgh & 8.5bcdef \\
\hline & HT14 & 66.7fghijkl & $0.7 \mathrm{~cd}$ & 48.9abc & 1.ocdefg & 10.1bcdefghi & 10.1bcdef \\
\hline & HT15 & 6o.oijkl & $0.5 \mathrm{~cd}$ & $43.5 \mathrm{bcdef}$ & o.9cdefg & 10.4abcdefg & 11.4bcdef \\
\hline & HT16 & 81.8cdefghi & $0.4 \mathrm{~cd}$ & $38.8 b c d e f g h$ & 1.1cdefg & $11.2 \mathrm{ab}$ & 11.7bcdef \\
\hline & HT17 & 65.ofghijkl & $3.1 \mathrm{~b}$ & $56.0 a$ & o.8efgh & $11.5^{a}$ & $13.9 \mathrm{~b}$ \\
\hline & HT19 & $97.7 \mathrm{bc}$ & $0.1 \mathrm{~d}$ & 44.4abcde & 1.ocdefg & 10.2bcdefghi & 11.1bcdef \\
\hline & HT2O & 78.3cdefghij & $0.2 \mathrm{~d}$ & 44.9abcde & 1.1cdefg & 9.9bcdefghij & 9.2bcdef \\
\hline & HT21 & $50.5 \mathrm{kl}$ & $1.2 \mathrm{~cd}$ & 46.3abcde & 1.3abcdefg & 10.4abcdefgh & 8.7 bcdef \\
\hline & HT22 & 74.1cdefghijk & $0.5 \mathrm{~cd}$ & 37.7bcdefgh & 1.1cdefg & 9.4ghijk & 8.9bcdef \\
\hline & HT23 & $56.7 \mathrm{jkl}$ & $0.4 \mathrm{~cd}$ & 44.6abcde & o.8efgh & 9.7cdefghij & 9.6bcdef \\
\hline & HT24 & $108.2 \mathrm{ab}$ & $0.6 \mathrm{~cd}$ & $36.8 \mathrm{cdefgh}$ & 1.1cdefg & 9.5efghij & $10.4 \mathrm{bcdef}$ \\
\hline & HT25 & $95 \cdot 3 \mathrm{bcd}$ & $1.3 \mathrm{~cd}$ & 37.7bcdefgh & $0.7 \mathrm{gh}$ & 9.9bcdefghij & 11.6bcdef \\
\hline & HT27 & 92.9bcde & $0.9 \mathrm{~cd}$ & $34.5 \mathrm{efghi}$ & 1.ocdefg & 10.3abcdefgh & 10.3bcdef \\
\hline & HT28 & 72.6defghijk & $0.1 d$ & 40.8bcdefg & 1.1cdefg & 10.1bcdefghi & 10.obcdef \\
\hline & HT29 & 66.5fghijkl & $2.5 \mathrm{bc}$ & 36.5 defgh & 1.4abcde & 9.8cdefghij & $9.3 \mathrm{bcdef}$ \\
\hline & $\mathrm{HT}_{4} 8$ & 76.3cdefghij & $0.4 \mathrm{~cd}$ & 38.8 bcdefgh & 1.3abcdefg & 10.2bcdefghi & 8.6bcdef \\
\hline & $\mathrm{HT}_{50}$ & $92.5 \mathrm{bcde}$ & $0.8 \mathrm{~cd}$ & 39.9bcdefgh & $1.5 \mathrm{abc}$ & 10.obcdefghi & 6.6def \\
\hline & HT53 & $93.4 \mathrm{bcde}$ & $0.4 \mathrm{~cd}$ & $47.2 \mathrm{abcd}$ & o.9defgh & 11.0abc & $12.5 \mathrm{bcd}$ \\
\hline & $\mathrm{HT}_{5}$ & 80.ocdefghij & o.od & 31.2ghi & $0.3 \mathrm{~h}$ & $8.2 \mathrm{k}$ & $22.8 \mathrm{a}$ \\
\hline & HT43 & $84.9 \mathrm{cdefgh}$ & $0.7 \mathrm{~cd}$ & 45.8abcde & 1. ocdefg & 10.1bcdefghi & 10.1bcdef \\
\hline & $\mathrm{HT}_{44}$ & 82.6cdefghi & $0.7 \mathrm{~cd}$ & $43.4 \mathrm{bcdef}$ & 1.ocdefg & 10.7abcdef & 10.5bcdef \\
\hline & HT46 & 66.1fghijkl & $0.3 \mathrm{~cd}$ & $48.2 \mathrm{abcd}$ & 1.2bcdefg & 9.5efghij & 7.9cdef \\
\hline & $\mathrm{HT}_{51}$ & $57.4 \mathrm{jkl}$ & $0.9 \mathrm{~cd}$ & $43.7 \mathrm{bcdef}$ & 1.ocdefg & 10.5abcdefg & 10.2bcdef \\
\hline & $\mathrm{HT}_{52}$ & 69.5efghijkl & $0.6 \mathrm{~cd}$ & 48.2abcd & o.9defgh & 9.7defghij & 11.7bcdef \\
\hline & HT56 & 63.7ghijkl & $0.7 \mathrm{~cd}$ & 42.3bcdefg & 1.5abcd & 9.9bcdefghij & 7.1cdef \\
\hline \multirow[t]{6}{*}{$\mathrm{C}_{3}$} & HT3O & 83.6cdefghi & $1.2 \mathrm{~cd}$ & $49.2 \mathrm{ab}$ & 1.2bcdefg & 9.6efghij & 8.8bcdef \\
\hline & $\mathrm{HT}_{32}$ & 76.6cdefghij & $1.1 \mathrm{~cd}$ & 28.2hi & 1.1cdefg & $8.9 \mathrm{ijk}$ & 9.5bcdef \\
\hline & HT33 & 86.9bcdefgh & $0.2 \mathrm{~d}$ & 32.4fghi & $0.8 f g h$ & $8.6 \mathrm{jk}$ & 12.4bcde \\
\hline & $\mathrm{HT}_{34}$ & 77.2cdefghij & $0.2 \mathrm{~d}$ & 43.1bcdefg & 1.ocdefg & 10.8abcde & 11.1bcdef \\
\hline & $\mathrm{HT}_{36}$ & $52.2 \mathrm{kl}$ & $0.3 \mathrm{~cd}$ & 32.2 fghi & 1.1cdefg & 9.1hijk & 8.2bcdef \\
\hline & HT61 & 62.7hijkl & 1.ocd & 45.4 abcde & 1.1cdefg & 9.2ghijk & 8.5bcdef \\
\hline \multirow[t]{2}{*}{$\mathrm{C}_{4}$} & $\mathrm{HT}_{7}$ & $59.8 \mathrm{ijkl}$ & $3.9 \mathrm{~b}$ & 38.7bcdefgh & 1.2bcdefg & 9.4fghijk & 8.5bcdef \\
\hline & HT8 & 82.4cdefghi & $3.6 \mathrm{~b}$ & 44.9abcde & 1.4abcde & $8.6 \mathrm{jk}$ & 6.5def \\
\hline $\mathrm{C}_{5}$ & HT49 & 80.3cdefghij & $0.5 \mathrm{~cd}$ & 40.4bcdefg & 1.4abcdef & 10.7abcdef & $7 \cdot 3 \mathrm{cdef}$ \\
\hline C6 & HT6 & 82.2cdefghi & $0.3 \mathrm{~d}$ & 42.2bcdefg & 1.1cdefg & 9.2ghijk & 8.4bcdef \\
\hline \multirow[t]{2}{*}{$\mathrm{C}_{7}$} & $\mathrm{HT}_{47}$ & 64.7ghijkl & $0.4 \mathrm{~cd}$ & 37.8bcdefgh & 1.3abcdefg & 8.9ijk & $7 \cdot 5 \mathrm{cdef}$ \\
\hline & HT59 & $125.0 \mathrm{a}$ & o.od & 32.ofghi & $0.7 \mathrm{gh}$ & 9.2ghijk & $12.8 \mathrm{bc}$ \\
\hline Control & 'Sidi Aissa' & 87.7bcdefg & $7.2 \mathrm{a}$ & $43.7 \mathrm{bcdef}$ & o.9defgh & 10.obcdefghi & 11.6bcdef \\
\hline
\end{tabular}

Within each column, the values bearing the same letters are significantly indifferent at $P>5 \%$. 
Table 3: Descriptive statistics, analysis of variance $(Y=y e a r, ~ G=$ genotypes, $[Y \times G]=$ their interaction) and coefficient of variation for some quality fruit characters in mandarin hybrids with mother control

\begin{tabular}{|c|c|c|c|c|c|c|}
\hline \multirow[t]{2}{*}{ Sources } & \multicolumn{6}{|l|}{ Mean squares } \\
\hline & $\begin{array}{l}\text { Mean fruit weight } \\
\text { (g) }\end{array}$ & $\begin{array}{l}\text { Fruit seed } \\
\text { number }\end{array}$ & $\begin{array}{l}\text { Juice content } \\
\text { (\%) }\end{array}$ & $\begin{array}{l}\text { Soluble } \\
\text { solids(TSS) }\end{array}$ & $\begin{array}{l}\text { Acidity } \\
\text { (TA) }\end{array}$ & TSS/TA \\
\hline Year (Y) & $9,043 \cdot 33^{* *}$ & $0.55 \mathrm{~ns}$ & $364.73^{* *}$ & $12.61 * *$ & $0.12 \mathrm{~ns}$ & $1.92 \mathrm{~ns}$ \\
\hline Genotype (G) & $684.07 * *$ & $10.22 * *$ & $125.87 * *$ & $1.72 * *$ & $0.25^{* *}$ & $17.14 *$ \\
\hline (Y) X (G) & $318.32 \mathrm{~ns}$ & $1.10 \mathrm{~ns}$ & $49.76 \mathrm{~ns}$ & $0.71 \mathrm{~ns}$ & $0.17 \mathrm{~ns}$ & $14.33 \mathrm{~ns}$ \\
\hline Error & 235.23 & 1.24 & 36.42 & 0.70 & 0.09 & 12.11 \\
\hline CV (\%) & 19.82 & 94.54 & 14.50 & 8.38 & 27.27 & $35 \cdot 39$ \\
\hline Average & 77.40 & 1.18 & 41.61 & 9.99 & 1.11 & 9.829 \\
\hline
\end{tabular}

NS: no significant, ${ }^{*}$ and ${ }^{* *}$ : significant at $5 \%$ and $0.1 \%$, respectively.

Table 4: Physico-chemical traits of mandarin hybrids according to year

\begin{tabular}{|c|c|c|c|c|c|c|}
\hline \multirow[t]{2}{*}{ Years } & \multicolumn{6}{|l|}{ Variables } \\
\hline & $\begin{array}{l}\text { Mean fruit } \\
\text { weight (g) }\end{array}$ & $\begin{array}{l}\text { Fruit seed } \\
\text { number }\end{array}$ & $\begin{array}{l}\text { Juice content } \\
\text { (\%) }\end{array}$ & $\begin{array}{l}\text { Soluble } \\
\text { solids(TSS) }\end{array}$ & $\begin{array}{l}\text { Acidity } \\
\text { (TA) }\end{array}$ & TSS/TA \\
\hline 2007 & $84.66 \mathrm{ab}$ & $1.29 \mathrm{a}$ & $37.16 \mathrm{~b}$ & $10.29 b$ & $0.82 \mathrm{c}$ & $13.15 \mathrm{a}$ \\
\hline 2008 & $67.85 \mathrm{c}$ & $1.07 a$ & $37.65 \mathrm{~b}$ & $9.83 b c$ & $0.96 c$ & $10.78 \mathrm{bc}$ \\
\hline 2009 & $59.55 \mathrm{c}$ & $0.95^{a}$ & $44.38 \mathrm{a}$ & $9.56 c$ & $1.37 \mathrm{a}$ & $6.59 \mathrm{~d}$ \\
\hline 2010 & $80.75 \mathrm{~b}$ & $1.61 \mathrm{a}$ & $40.97 \mathrm{ab}$ & $9.46 c$ & $1.00 \mathrm{bc}$ & $9.28 \mathrm{c}$ \\
\hline 2011 & $84.86 \mathrm{ab}$ & $1.09 a$ & $41.87 \mathrm{ab}$ & $10.07 \mathrm{bc}$ & $1.06 \mathrm{bc}$ & $11.02 \mathrm{bc}$ \\
\hline 2012 & $89.37 a b$ & $1.16 \mathrm{a}$ & $42.71 \mathrm{ab}$ & $10.18 b$ & $1.22 \mathrm{ab}$ & $9 \cdot 31 \mathrm{c}$ \\
\hline 2013 & $96.36 \mathrm{a}$ & $1.52 \mathrm{a}$ & $44.57 a$ & $11.73 a$ & $1.00 b c$ & $11.97 \mathrm{ab}$ \\
\hline \multicolumn{7}{|l|}{ Range } \\
\hline 2007 & $5^{0-125}$ & $0-9$ & $20-50$ & $8-12$ & $0.36-1.38$ & $9-23$ \\
\hline 2008 & $45-90$ & $0-5$ & $23-47$ & $8-11$ & $0.60-1.43$ & $7-17$ \\
\hline 2009 & $29-85$ & $0-4$ & $23-62$ & $8-11$ & $0.61-2.20$ & $5^{-13}$ \\
\hline 2010 & $55^{-110}$ & $0-10$ & $25-50$ & $8-11$ & $0.77-1.62$ & $6-14$ \\
\hline 2011 & $50-140$ & $0-6$ & $27-67$ & $9-11$ & $0.55^{-1.70}$ & $4-23$ \\
\hline 2012 & $70-115$ & $0-12$ & $26-50$ & $8-12$ & $0.54-1.70$ & $5-23$ \\
\hline 2013 & $55-125$ & $0-8$ & $35-54$ & $10-14$ & $0.70-1.26$ & $8-16$ \\
\hline
\end{tabular}

Within each column. the values bearing the same letters are significantly indifferent with $P>5 \%$. Juice analysis dates: D1: 22/10/2007; D2: 16/10/2008; D3: 07/10/2009; D4: 29/10/2010; D5: 26/10/2011; D6: 29/10/2012; D7:17/10/2013.

The final rate of selection was $15 \%$ (table 6). Currently, special attention is paid to the risk of pollination and the isolation of clementine orchards and other seedless varieties [41]. As a result, the cultivation of mandarin Wilking has been officially banned in Morocco to avoid the production of clementines with too many seeds. But, this mandarin has a great scientific interest in the program of creation of triploid mandarins. It has been used as a male parent in directed crosses between diploid mandarins and has resulted in relatively high numbers of immature embryos and triploid hybrids [9]. Therefore, it can be seen that the families with male parents Wilking and Osceola having showed a greater improvement in the population when crossed with female parent Sidi Aissa. The true seedlessness can be obtained by selection among triploid genotypes [42]. Another study [43] revealed the female parent will determine the success rate of hybridization. Many citrus triploid hybrids have originated from sexual hybridizations $[6,44,45,3]$.

Table 5: Study male parent effect on fruit quality variation according to seven series of crosses

\begin{tabular}{|c|c|c|c|c|c|c|}
\hline \multirow{2}{*}{$\begin{array}{l}\text { Crosse } \\
\text { s }\end{array}$} & \multicolumn{6}{|l|}{ Variables } \\
\hline & $\begin{array}{l}\text { Mean fruit weight } \\
\text { (g) }\end{array}$ & $\begin{array}{l}\text { Fruit seed } \\
\text { number }\end{array}$ & $\begin{array}{l}\text { Juice content } \\
(\%)\end{array}$ & $\begin{array}{l}\text { Soluble solids } \\
\text { (TSS) }\end{array}$ & $\begin{array}{l}\text { Acidity } \\
\text { (TA) }\end{array}$ & $\begin{array}{l}\text { TSS/T } \\
\text { A }\end{array}$ \\
\hline $\mathrm{C} 1$ & $78.0 \mathrm{c}$ & $0.91 \mathrm{~b}$ & $41.35 \mathrm{~b}$ & $1.17 a$ & $10.20 \mathrm{a}$ & $9.58 \mathrm{~b}$ \\
\hline $\mathrm{C}_{2}$ & $72.0 \mathrm{c}$ & $0.57 \mathrm{~b}$ & $43.26 a$ & $1.02 \mathrm{ab}$ & $9.81 a$ & $11.46 a$ \\
\hline $\mathrm{C}_{3}$ & $73.2 \mathrm{c}$ & $0.66 \mathrm{~b}$ & $38.41 \mathrm{c}$ & $1.06 \mathrm{ab}$ & $9.39 \mathrm{ab}$ & $9.74 \mathrm{~b}$ \\
\hline $\mathrm{C} 4$ & $71.1 \mathrm{c}$ & $3.75 a$ & $41.84 \mathrm{~b}$ & $1.32 \mathrm{a}$ & $9.05 \mathrm{~b}$ & $7.53 \mathrm{c}$ \\
\hline $\mathrm{C}_{5}$ & $80.3 \mathrm{~b}$ & $0.47 \mathrm{~b}$ & $40.42 \mathrm{~b}$ & $1.37 \mathrm{a}$ & $10.72 a$ & $7.26 \mathrm{c}$ \\
\hline $\mathrm{C} 6$ & $73.4 \mathrm{c}$ & $0.33 \mathrm{~b}$ & $39.97 \mathrm{c}$ & $1.20 \mathrm{a}$ & $9.07 \mathrm{~b}$ & $7.97 \mathrm{c}$ \\
\hline $\mathrm{C}_{7}$ & $106.4 a$ & $3.61 a$ & $37.69 \mathrm{c}$ & $0.79 \mathrm{~b}$ & $9.61 \mathrm{ab}$ & $12.20 \mathrm{a}$ \\
\hline Means & 79.2 & 1.47 & 40.42 & 1.13 & 9.69 & 9.39 \\
\hline$S D$ & 12.45 & 1.52 & 1.94 & 0.20 & 0.61 & 1.93 \\
\hline
\end{tabular}

Within each column, the values bearing the same letters are significantly indifferent with $P>5 \%$. 
Table 6: Selection rate of triploid hybrids according to seven crosses mandarins

\begin{tabular}{|c|c|c|c|c|c|}
\hline & Parents $(\hat{O} \boldsymbol{X}+)$ & $\begin{array}{l}\text { Total } \\
\text { number }\end{array}$ & $\begin{array}{l}\text { Selection } \\
\text { number }\end{array}$ & $\begin{array}{l}\text { Selection } \\
\text { rate(\%) }\end{array}$ & Triploids hybrids seleted \\
\hline C1 & Sidi Aissa $X$ Wilking & 21 & 3 & 14.29 & HT11, HT13, HT27 \\
\hline C2 & Sidi Aissa X Osceola & 7 & 2 & 28.57 & $\mathrm{HT}_{43}, \mathrm{HT}_{44}$ \\
\hline$C_{3}$ & Sidi Aissa X Chienka & 6 & - & - & - \\
\hline$C_{4}$ & Sidi Aissa XSatsuma Frost & 2 & - & - & - \\
\hline C5 & Sidi Aissa X Caravalhal & 1 & 1 & 100 & HT49 \\
\hline C6 & Sidi Aissa X Lee & 1 & - & - & - \\
\hline \multirow[t]{2}{*}{$C 7$} & Sidi Aissa X SastumaOwari & 2 & - & - & - \\
\hline & Total & 40 & 6 & 15.00 & \\
\hline
\end{tabular}

C1: Croisement (Sidi Aissa X Wilking) C2: Croisement (Sidi Aissa X Osceola);C3: Croisement (Sidi Aissa X Chienka) C4: Croisement (Sidi Aissa X Satsuma Frost)C5: Croisement (Sidi Aissa X Caravalhal) C6: Croisement (Sidi Aissa X Lee) C7: Croisement (Sidi Aissa X Satsuma Owari)

Table 7: Diameter and shape of fruits of promising mandarin hybrids

\begin{tabular}{llllll}
\hline Crosses & $\begin{array}{l}\text { Selected } \\
\text { hybrids }\end{array}$ & $\begin{array}{l}\text { Diameter (D) } \\
\text { (mm) }\end{array}$ & $\begin{array}{l}\text { length (P) } \\
\text { (mm) }\end{array}$ & $\mathbf{( D / P )}$ & Shape \\
\hline C1 & HT11 & 61,14 & 60,00 & 1,02 & Pyriform and round \\
C1 & HT13 & 61,14 & 60,00 & 1,02 & Pyriform and round \\
C1 & HT27 & 68,11 & 53,11 & 1,28 & flattened \\
C2 & HT43 & 66,61 & 54,60 & 1,21 & flattened \\
C2 & HT44 & 63,91 & 50,41 & 1,27 & flattened \\
C5 & HT49 & 61,14 & 60,00 & 1,02 & Pyriform and round \\
Control & Sidi Aissa & 62,86 & 51,52 & 1,22 & flattened \\
\hline
\end{tabular}

(D/P indicator of fruit shape if $\mathrm{D} / \mathrm{P}=1$, the fruit is round)

\section{Pomological study of promising mandarin hybrids}

The coloring of fruit bark is among the most important quality criteria that influence the perception and appreciation of consumers. Generally, it depends on the climatic conditions [41]. The selected hybrids HT43, HT 44 and HT49 have an attractive dark orange rind, while the others are yellowish (fig. 3). All triploids hybrids selected were characterized by sweet flavor, medium fruits, easily to peel, firm fruits with thin epicarp $(<2 \mathrm{~mm})$ and weak adherence of segment walls. In addition, they have a flattened shape except for the hybrid HT11, HT13 and HT49 which have a pyriform and round shape (table 7).

\section{CONCLUSION}

Triploid mandarin hybrids selected were grafted on several rootstocks in order to complete the present study by multifocal varietal trials. The hybrids selected will be registered in the Moroccan official catalog, multiplied and then put at the disposal of the nurserymen. The seedlessness illustrates this interest of the triploids. Thus, spontaneous triploidy is a promising way for the selection of seedless mandarin fruit varieties, but, still remains the frequency of relatively low triploid compared to crosses (2x X 4x).
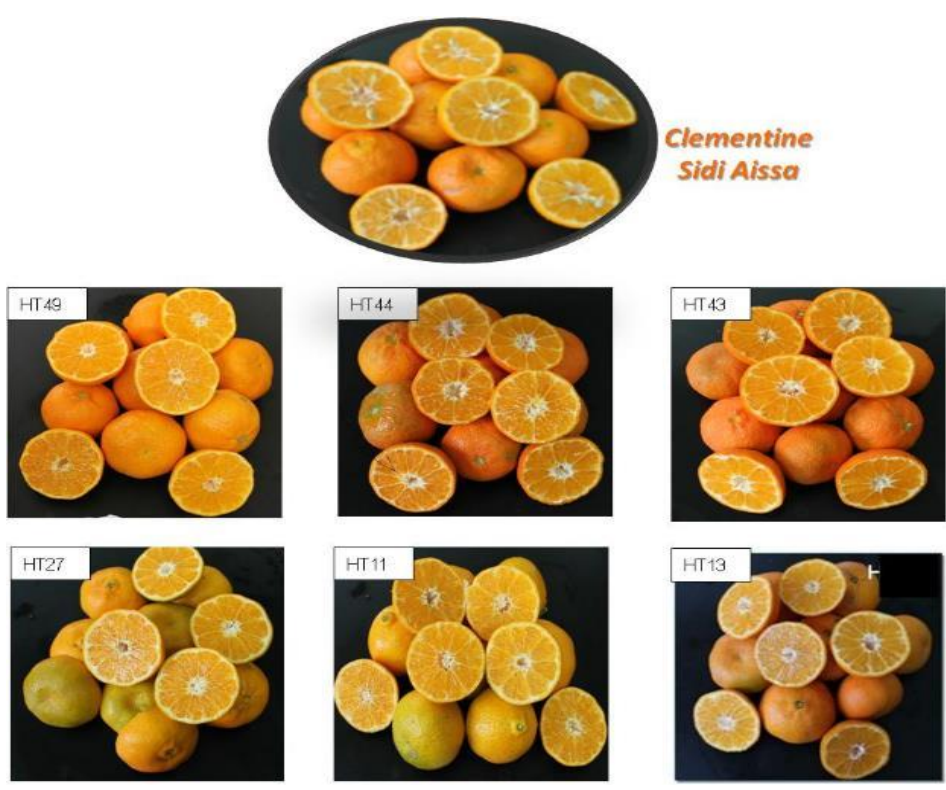

Fig. 3: New promising mandarin seedless triploid hybrids compared to mother plant Clementine Sidi Aissa 


\section{ACKNOWLEDGMENT}

The authors thank the PhD student Aderdour Tarik who did all the statistical analysis.

\section{REFERENCES}

1. Ray, PK. Citrus. In: Breeding Tropical and Subtropical Fruits. Narosa Publishing House. 2002;84-106.

2. Jenks, M. A., Bebeli, P. Breeding for Fruit Quality. John Wiley andSons. Inc,Oxford, UK. 2011;400.

3. Aleza, P., Juárez, J., Cuenca, J., Ollitrault, P., Navarro, L. Extensive citrus triploid hybrid production by 2xX4x sexual hybridizations and parent-effect on the length of the juvenile phase. Plant Cell Reports. 2012;31: 1723-1735.

4. Otto SP, and Whitton J. Polyploid incidence and evolution. Annu. Rev. Genet.2000;34, 401-437.

5. Navarro, L., Juárez J, Aleza, P., Pina, J. A. Proc. of the 10th IAPTCandB Congress Recovery of triploid seedless mandarin hybrids from $2 n \times 2 n$ and $2 n \times 4 n$ crosses by embryo rescue and flow cytometry (Plant Biotechnology and Beyond, Orlando, FL). 2002;541-544.

6. Esen A, Soost RK. Unexpected triploids in Citrus: their origin, identification and possible use. Journal of Heredity. 1971;62:329-333.

7. Geraci, G., Esen A., Soost, RK. Triploid progenies from 2xX2x crosses of Citrus cultivars. Journal of Heredity. 1975;66:177-178.

8. Luro, F., Maddy F., Jacquemond C., Froelicher Y., Morillon R., Rist D., Ollitrault P. Identification and evaluation of diplogyny in clementine (Citrus clementina) for use in breeding. Acta Horticulturae. 2004;663: 841-848.

9. Handaji, N., Dambier, D., Chahbar, A., Arsalane, N., Hmouni, D., Benyahia, H., Ollitrault, P. Etude de facteurs influents sur la production de triploïdes par hybridation entre clémentiniers et mandariniers diploïdes. Al Awamia. 2005;113:27-46.

10. Handaji N., N. Arsalane, H. Ben Yahia. Et M. Ibriz. Identification de l'origine de gamètes parentaux diploïdes et mode de restitution nucléaire des hybrides spontanément triploïdes de mandariniers. AlAwamia. 2008;123/124:120-135.

11. Ollitrault, P., Dambier, D., Luro F, Froelicher, Y. Ploidy manipulation for breeding seedless triploid citrus. Plant Breeding Reviews.2008;20:323-354.

12. Ollitrault, P., Luro, F, Yamamoto, M. Seedlessness and ploidy manipulations. In: IA Khan. Citrus Genetics, Breeding and Biotechnology. CABI: Wallingford, UK.2007.

13. Fatta Del Bosco, S., G. Matrango and G. Geraci. Micro and macro sporogenesis of two triploid hybrids of citrus. In: Proc. Int. Soc. Citriculture. 1992;1:122-4

14. Kaneyoshi, S., Ohgawara, T., Saito, W., Nakamura, Y., Omura, M. Production of triploid somatic hybrids in Citrus. J. Jpn. Soc. Hort. Sci. 1997;66:453-458.

15. Recupero, G. R., Russo G., Recupero, S. New promising citrus triploid hybrids selected from crosses between monoembryonic diploid female ant tetraploid male parents. HortScience. 2005;40:516-520.

16. Tokunaga, T., Miyahara, K., Tabata, K., Esaka, M. Generation and properties of ascorbic acidoverproducing transgenic tobacco cells expressing sense RNA for L-galactono-1, 4-lactone dehydrogenase. Planta. 2005;220:854-63.

17. Ollitrault, P., Jacquemond, C., Dubois, C., Luro, F. In: Genetic diversity of cultivated tropical plants. Hamon
P, Seguin M, Perrier X, Glaszmann J, editor. Paris: Science Publishers and Cirad. Citrus. 2003;193-217.

18. Aleza, P., Juárez, J., Ollitrault, P., Navarro, L. Production of tetraploid plants of non-apomictic citrus genotypes. Plant Cell Reports. 2009;28:1837-1846.

19. Padoan, D., Khan, P. S. S. V., Chiancone, B., Barany, I., Risueno, M. C., Testillano, P. First stages of microspore reprogramming to embryogenesis through isolated microspore culture in Eriobotrya japonica lindl. Acta Hortic. 2011;887:285-289.

20. Nadori, E. B., Ouammou, M., Kayaf M. Comportement de trois clones de clémentinier sur différents portegreffes, AL Awamia. 1988;64:44-54.

21. Pech, J. C., Balagué, C., Latché, A., Bouzayen, M. Postharvest physiology of climacteric fruits: recent developments in the biosynthesis and action of ethylene. Sci Alim. 1994;14:3-15.

22. Cuenca, J., Aleza, P., Juárez, J., Pina, J. A., Navarro, L. 'Safor' mandarin: a new citrus midlate triploid hybrid. HortScience. 2010;45:977-980.

23. Aleza, P., Cuenca, J., Juárez, J., Pina, J. A., Navarro, L. 'Garbi' mandarin: a new late-maturing triploid hybrid. Hort Science. 2010a; 45: 139-141.

24. Iqbal, M., Khan M. N., Zafar, M., Munir, M. Effect of harvesting date on fruit size, fruit weight and total soluble solids of feutrell's early and kinnow cultivars of Mardan (Citrus Reticulata) on the economic conditions of farming community of Faisalabad. Sarhad J. Agric. 2012;28: 19-21.

25. Lado, Joanna, MaríaJesús Rodrigo, and Lorenzo Zacarías. Maturity indicators and citrus fruit quality: Stewart Postharvest Review. 2014;2:2-6.

26. Russo, G., Fanizza, G. Genotypic variability and interrelationships among Morphological and biochemical fruit Characters in Mandarins. Proc In. Soc. Citriculture. 1991;7:96-97.

27. Etxeberria, E., Gongalez, P., Pozueta, R. J. Sucrose transport into citrus juice cells. Evidence for andocytic transport system. J Am SocHort Sci. 2005;130:269274.

28. Iglesias DJ, Cercós M, Colmenero-Flores JM. Physiology of citrus fruiting. Brazilian Journal of Plant Physiology. 2007;19:333-362.

29. Albertini, M. V., Carcouet, E., Pailly, O., Gambotti, C., Luro, F. and Berti, L. Changes in organic acids and sugars during early stages of development of acidic and acidless citrus fruit. Journal of Agricultural and Food Chemistry. 2006;54:8335-8339.

30. Liu FuWen, Liang YinChih, Wang YeeDing. A simple method of spot-picking for higher quality 'Ponkan' mandarins by selecting locations of the tree. Journal of the Taiwan Society for Horticultural Science. 2012;58:11-18.

31. Ashraf, M. Y., Yaqub, M., Akhtar, J., Khan, M. A., AliKhan, M. and Ebert, G. Control of excessive fruit drop and improvement in yield and juice quality of Kinnow (Citrus deliciosa x Citrus nobilis) through nutrient management. Pak. J. Bot. 2012;44:259-265.

32. Handaji, N., Arsalane, N., Ait Haddou, M. M., Kabbaj, T., Srairi, I., Benyahia, H., Rahmouni, A., Gabonne, F. Caractérisation et comportement de 35 variants d'agrumes au niveau de la région de Souss. AlAwamia. 2007;121/122:110-134.

33. Handaji, N., Benyahia H, Arsalane N, Ben Azouz A., Gaboun F. Evaluation pomologique et organoleptique de 34 variants d'orangers (Citrus sinensis (L.) Osbeck) 
issus de semis apomictique en essai dans la région du Gharb Al AwAmiA. 2013;127:47-70.

34. Zekri, M. Factors affecting citrus fruit production and quality. Citrus Industry. 2011;92: 6-9.

35. Zhang, Yi, Liu, JiWu, Du Li. Changes of color, sugar and acid content in flesh of Citrus reticulate during maturity period. Guizhou Agricultural Sciences. 2012;2:142-144.

36. Sdiri, S., Navarro, P., Monterde, A., Benabda, J., Salvador, A. Effect of postharvest de greening followed by a cold-quarantine treatment on vitamin C, phenolic compounds and antioxidant activity of early-season citrus fruit. Postharvest Biology and Technology. 2012;65:13-21.

37. Chen, Si., Huang Qing Hua, You Ming Xia, Wu Shao Hui, Li Rao Ling, Gan Wei Fa. Analysis of polysaccharides compositions in ripe peel of Citrus reticulate 'Chachi'. The Journal Board of Medicinal Plant, Cranston, USA, Medicinal Plant. 2012;3 : 26-29.

38. Abouzari, A., Nezhad N. M. The Investigation of citrus fruit quality popular characteristic and breeding. Acta Universitatis Agriculturae Silviculturae Mendelianae Brunensis. 2016;64:725-740.

39. Combrink, N. K., Labuschagne,M. T., Bijzet, Z. Variation of fruit size and shape in Kiyomitangor families. Scientia Horticulturae. 2013;162: 357-364.
40. Porras, I., Brotons, J. M., Conesa, A., Castañer, R., Pérez-Tornero, O., Manera, F. J. Quality and fruit colour change in Verna lemon. Journal of Applied Botany and Food Quality. 2015;88, 215-221.

41. Fatta Del Bosco S., Siragusa, M., Abbate, L., Lucretti, S., Tusa, N. Production and characterization of new triploid seedless progenies for mandarin improvement. Scientia Horticulturae. 2007;114:258-262.

42. Zhang, C. H., Zhang, S. L., Shen, S. X., Wang, M., Wang, Y. H. 2001. Observation on obtaining the triploid by $4 \mathrm{x} \times 2 \mathrm{x}$ and its cytoembryology in false pakchoi. Acta Horticulture Sinica. 2001;28:317-322.

43. Williams TE, Roose ML 'TDE2' Mandarin hybrid (Shasta Gold Ò Mandarin), 'TDE3' Mandarin hybrid (Tahoe Gold Ò Mandarin) and 'TDE4' Mandarin hybrid (Yosemite Gold Ò Mandarin): three new mid and late-season triploid seedless mandarin hybrids from California. In: Proceedings of 1oth international citrus congress, vol 1, International Society of Citriculture, Agadir, Marruecos. 2004;pp 394-398.

44. Viloria, Z. J., W. Grosser, B. Bracho. Immature embryo rescue, culture and seedling development of acid citrus fruit derived from interploid hybridization. Plant Cell, Tissue and Organ Culture. 2005;82:159167. 